\title{
Tapping Reeve, Coverture and America's First Legal Treatise
}

\author{
Angela Fernandez \\ Version Published PDF \\ Citation Angela Fernandez, "Tapping Reeve, Coverture and America's First \\ (published version) Legal Treatise" in Angela Fernandez \& Markus D. Dubber eds, Law \\ Books in Action: Essays on the Anglo-American Legal Treatise \\ (Oxford: Portland, Oregon: Hart Publishing, 2012) 63.
}

Publisher's Statement Angela Fernandez, "Tapping Reeve, Coverture and America's First Legal Treatise" in Angela Fernandez \& Markus D. Dubber eds, Law Books in Action: Essays on the Anglo-American Legal Treatise (Oxford: Portland, Oregon: Hart Publishing, 2012) 63. Copyright $\mathbb{C}$ [2012]. Reprinted by permission of Hart Publishing.

How to cite TSpace items

Always cite the published version, so the author(s) will receive recognition through services that track citation counts, e.g. Scopus. If you need to cite the page number of the author manuscript from TSpace because you cannot access the published version, then cite the TSpace version in addition to the published version using the permanent URI (handle) found on the record page.

This article was made openly accessible by $U$ of $T$ Faculty. Please tell us how this access benefits you. Your story matters. 


\title{
Tapping Reeve, Coverture and America's First Legal Treatise
}

\author{
Angela Fernandez
}

By marriage, the husband and wife are one person in law: that is, the very being or legal existence of the woman is suspended during the marriage, or at least is incorporated and consolidated into that of the husband: under whose wing, protection, and cover, she performs every thing; and is therefore called in our lawfrench a feme-covert; is said to be covert-baron, or under the protection and influence of her husband, her baron, or lord; and her condition during her marriage is called her coverture.

William Blackstone, Commentaries on the Laws of England (1765)

The husband and wife in legal consideration are one person, her existence is united with and swallowed up in that of the husband [...] As the law contemplates the husband and wife as being but one person, it allows them to have but one will, which is placed in the husband, as the fittest and ablest to provide for and govern the family[.]

Zephaniah Swift, A System of the Laws of the State of Connecticut (1795)

The law does not view the husband and wife as one person[.]

Tapping Reeve, Baron and Femme (1816)

\section{Introduction}

Tapping Reeve wrote in his treatise on domestic relations the following surprising statement: 'The law does not view the husband and wife as one person'. ${ }^{1}$ Surprising because we have come to think of Blackstone's insistence that a husband and wife were one person and the famous passage above from his Commentaries about coverture as a final and authoritative statement of the law, grounded as it was on that second bible of English common law in the colonies, Coke Upon Littleton. ${ }^{2}$ One would have thought that Coke plus Blackstone created firm ground if ever there was any on the point in

\footnotetext{
* Angela Fernandez is currently an associate professor at the Faculty of Law, University of Toronto. Her chapter for this collection is material adapted from her JSD Dissertation, supervised by Robert W Gordon at the Yale Law School. Funding assistance for that project was provided by the Social Sciences and Humanities Research Council of Canada Doctoral Award and Lillian Goldman Scholarships provided by Yale Law School. The portions of the work drawn on here owe thanks to then-director of the Rare Book Room at Yale Law School, Harvey Hull, and staff at the Litchfield Historical Society in Litchfield and the Connecticut Historical Society in Hartford, as well as the very sadly nowdeceased Morris L Cohen. Sooin Kim and Sufei Xu of the Bora Laskin Library at the Faculty of Law, University of Toronto have been very helpful with the subsequent research that has gone into the piece.

${ }^{1}$ T Reeve, The Law of Baron and Femme; of Parent and Child; of Guardian and Ward; of Master and Servant; and of the Powers of Courts of Chancery (New Haven, CT, Oliver Steele, 1816) 89.

${ }^{2}$ See Commentaries on the Laws of England, A Facsimile of the First Edition of 1765-1769, vol I, Of the Rights of Persons (1765) (Chicago, IL, University of Chicago Press, 1979, 2002) 430, n 1 (citing 'Co. Litt. 112'). See also T Stretton, 'Coverture and Unity of Person in Blackstone's Commentaries' in W Prest (ed), Blackstone and His Commentaries: Biography, Law, History (Oxford, Hart Publishing, 2009) 111, 115-16 (explaining that the passage in Coke Upon Littleton that Blackstone relied on was in a chapter on 'tenure in burgage, one of the most obscure forms of tenure in English law' and that 'Littleton and Coke made reference to unity of person, but neither author relied on it to any great extent').
} 
nineteenth-century American law. It is certainly treated that way by both lawyers and historians of married women's property rights who have taken little notice of Reeve. ${ }^{3}$ Tapping Reeve taught students at his school in Litchfield, Connecticut and wrote in his treatise that the language of oneperson-in-law was 'metaphorical' only. ${ }^{4}$ How could it not be, Reeve asked, when one found that a married woman was 'often an active agent, executing powers, conveying land, suing with her husband, and liable to be sued with him, and liable to punishment for crimes'? ? $^{5}$ Reeve argued that coverture could not mean that the legal existence of a woman was subsumed by her husband or suspended for the term of the marriage since she could still be a guardian and give a receipt. The power to engage in such activities showed that it could not be true that a wife "has no existence during the coverture, and is destitute of volition'. ${ }^{6}$ The maxim that a wife had no will had 'not the least foundation in common sense'. ${ }^{7}$ She should, for instance, be allowed to make a will, one of the very basic entitlements of a subject with legal personality. ${ }^{8}$

Why did Reeve take such a surprising position? What hope did this reverse-principle ever have of carrying the day? Lest Reeve's position appear to be some kind of quaint aberration, it must be said that in fact his views had noteworthy effect. The most dramatic evidence of this is a statute Reeve's students passed in the Connecticut legislature in 1809 empowering married women to make wills. Scholars of married women's property law have found it puzzling why this statute appeared so early (especially in Connecticut which was known for being particularly restrictive of women's property rights) when reform enabling married women to bequeath property did not occur in most states until after 1850. ${ }^{9}$ Well, evidence suggests that the Connecticut legislature was filled with Reeve's students, who were exposed to his passionate arguments on the issue and were convinced enough by them to pass the law. ${ }^{10}$ The other place to look for evidence of influence is subsequent legal commentary. James Kent, while generally keen on Reeve's work, did not agree with Reeve's position on the legal personality of married women and declined to follow it in his famous Commentaries on American Law. ${ }^{11}$ Kent chose Coke (and impliedly Blackstone) instead. ${ }^{12}$ However, Nathan Dane, in his abridgement on American law, did follow Reeve, showing that not only was Reeve's book an important one, Reeve was persuasive to some on this most controversial point, rejection of the oneperson-in-law maxim. Relying directly on Reeve, Dane wrote 'the notion that a wife has no will, is a mere fiction without foundation in fact' ${ }^{13}$ Reeve influenced students and early American legal culture more generally through his school and his treatise, a truly didactic or teaching text. The second question, why Reeve put forward the position he did, is more difficult to answer. It relates as we will see to Reeve's religion, his own marriage and conditions that were unique to Connecticut during this period.

The first quarter of the nineteenth century was a time in post-Revolutionary America when many legal issues were up for grabs. In a way, the independence Reeve exhibited in his treatise was simply

${ }^{3}$ But see N Basch, In the Eyes of the Law: Women, Marriage, and Property in Nineteenth-Century New York (Ithaca, NY, Cornell University Press, 1982) 42-69 (who makes an exception for Reeve in her line-up of largely conservative writers on married women's property law — Blackstone, Kent and Story); H Hartog, Man and Wife in America: A History (Cambridge, MA, Harvard University Press, 2002) 107 (calling Reeve's book 'the most important American treatise dealing with marriage during the first half of the nineteenth century' and noting that it 'entirely avoided the language of unity').

${ }^{4}$ Reeve, Baron and Femme 129.

${ }^{5}$ Ibid 130.

${ }^{6}$ Ibid 121 .

${ }^{7}$ Ibid 64.

${ }^{8}$ This subject occupies two chapters of Baron and Femme and will be explored in detail below. See ibid 137-60.

${ }^{9}$ See RH Chused, 'Married Women's Property Law: 1800-1850' (1983) 71 Georgetown Law Review 1359, 1366.

${ }^{10}$ See text below at notes $81-88$.

${ }^{11}$ For reliance on Baron and Femme, see J Kent, Commentaries on American Law, vol 2 (New York, NY, O Halsted, 1827) $67,78,88,108,163,165,185,189,205,211,148-49$.

${ }^{12}$ See ibid 109 ('[t]he legal effects of marriage, are generally deducible from the principle of the common law, by which the husband and wife are regarded as one person, and her legal existence and authority in a degree lost or suspended, during the continuance of the matrimonial union', citing for support to the same obscure passage in Coke Upon Littleton that Blackstone referred to, 'Co. Litt. 112').

${ }^{13}$ Nathan Dane, General Abridgement and Digest of American Law, vol 1 (Boston, MA, Cummings, Hilliard, 1823$) 371$. Dane relied on Baron and Femme to state that a married woman 'is, in no sense, an idiot or non compos; nor does the criminal law view her as one ... [E]ven the laws of property view her as able to convey or devise, and even alone, where her husband has no interest affected thereby, as where she executes a power by trustee, [and] has separate property'. 
in keeping with the express legal philosophy that, after the Revolution, Connecticut did not have to follow English common law and, indeed, it should not if that law was wrong or made no sense. Rejection of the Coke/Blackstone maxim was certainly in keeping with this, however out of step it might be with what we have learned about the law of husband and wife in the nineteenth century. However, Reeve did not present his arguments as part of Connecticut's right to go its own way or a continuation of what we will see was a Puritan orientation in the law specific to New England. Rather Reeve called what he wrote in the treatise 'English law' that was of concern to Connecticut and other states in the Union. While he included discussion of some English statutes and cases, we will see that by and large Reeve argued from what I will call 'pure principle', not only ignoring local Connecticut cases (those for and against) but going so far as to ignore positive law like the 1809 statute that actually supported and vindicated him. How are we to understand such odd behaviour in a legal treatise?

When Roscoe Pound lectured in 1936 about the 'taught law' tradition and its connection to Kent's Commentaries and treatise writers like Joseph Story and later John Henry Wigmore and Samuel Williston, he used Reeve's Baron and Femme to mark the beginning of 'American text writing as a significant force in our legal development', identifying it in effect as the first American legal treatise. ${ }^{14}$ It might be something of a stretch to call the work a treatise. Reeve himself did not do so in his title, nor, we should note, did Pound. While Baron and Femme is written on a specialised topic, constituting a treatment of the law of husband and wife, it is really a collection of Reeve's lectures and might well be judged to be not rigorous or systematic enough in its arrangement or presentation in order to qualify as a treatise. However, we should note that later editors who updated Reeve's text did not hesitate to call it a treatise. ${ }^{15}$ And Reeve's book is nothing if not a statement of principle. Indeed, the issue is not a want of principle; it is rather the absence of precedent that makes it an odd legal treatise.

We have come to think of the legal treatise as a place where an expert (lawyer, judge, academic) commits to paper explanations of legal doctrine supported by sources of positive law: cases and statutes (at a bare minimum). Such a treatise becomes persuasive and authoritative (if it does) in part because of who the writer is; but that judgment is also based in part on the sense that develops in the relevant legal community that the author can be trusted in his or her use of the positive legal sources. When a treatise writer pushes and wants to move from the descriptive to the normative, there is usually a signal to that effect, a mark to the reader, a 'we might suggest' or 'it seems to us' ${ }^{16}$ What is striking about Baron and Femme is that Reeve does not do this. He does not report what the cases say, for instance, and then go on to argue that they were wrongly decided; he simply ignores the cases and statute law and argues for what he thinks the law ought to be. In the case of married women making wills, it makes no sense to say married women have no will and so a default common law presumption that they cannot make a will cannot be correct. No doubt many treatise writers play some sleight of hand with the cases, burying points to the contrary in footnotes no one will follow up on or justifying exclusion of problematic or complicating cases on the grounds that the case is badly reasoned, the court is not of a sufficiently high authority, or the point of view is considered by those in the know as old or out of date. ${ }^{17}$ Indeed, '[t] he reader who blinks' might well miss the treatise writer's shift from descriptive to normative, always a slippery line at best. ${ }^{18}$ But excluding the most relevant cases and excluding positive law that actually supports the point? This seems to stretch the limit. However, Reeve did just that in Baron and Femme. He simply did not seem to feel the need to be bound in his treatise in the ordinary positivist ways. Instead he capitalised on a moment in which a

\footnotetext{
${ }^{14}$ R Pound, The Formative Era of American Law (Boston, MA, Little, Brown, 1938) 144, 140. See also R Pound, 'Taught Law' (1912) 3 American Law School Review 164.

${ }^{15}$ See Preface to T Reeve, The Law of Baron and Femme 2nd edn, L E Chittenden (ed) (Burlington, VT, Chauncey Goodrich, 1846) iii; Preface to T Reeve, The Law of Baron and Femme 3rd edn, A J Parker \& C Baldwin (eds) (Albany, NY, Gould, 1862) iii.

${ }^{16}$ See S Waddams, 'What Were the Principles of Nineteenth-Century Contract Law?' in L Andrew, P Brand and P Mitchell (eds), Law in the City: Proceedings of the Seventeenth British Legal History Conference, London, 2005 (Dublin, Four Courts Press, 2007) 308.

${ }^{17}$ Neil Duxbury has written about Frederick Pollock, for instance, that he 'had a crafty knack for slipping his own perspectives into his doctrinal expositions and passing them off as if they were law'. See N Duxbury, Frederick Pollock and the English Juristic Tradition (Oxford, UK; New York, NY, Oxford University Press, 2004) 269.

${ }^{18}$ Ibid 222.
} 
legal scholar could (somewhat surprisingly) actually invoke English law as a way to challenge or contradict a formulation of that common law in a new environment. This is extremely interesting, creating in effect a version of English law that no English lawyer would agree with, evidenced in this case by rejection of the one-person-in-law maxim. Reeve's treatise was teaching and speaking to lawyers in early America, invoking the authority of the common law while simultaneously challenging and re-creating it. In doing so, he acted as a typical 'fading Federalist', using whatever authority he still possessed (as a judge, teacher and treatise writer) to fashion a new American common law, only loosely connected to England and tied very much to local conditions, despite what it formally claimed and disclaimed. ${ }^{19}$

\section{Can A Married Woman Make A Will?}

In the preface to Baron and Femme, Reeve wrote that 'the governing principle' of each subject must be viewed as the 'pole-star' ${ }^{20}$ In the case of a will, the 'pole-star' was the intention of the testator. In England, married women were expressly prohibited from being testators by statute. A sixteenthcentury statute expressly listed married women among those legally incapable of making a will. Connecticut did not formally receive English law after the Revolution. There was no reception statute. $^{21}$ And so English statute law, like English common law, did not formally bind the territory. Connecticut jurists like Reeve's own teacher, Jesse Root, stated that the common law of England was not the common law of Connecticut. ${ }^{22}$ And while '[t]he common law of England we are to pay great deference to ... the rules, however, which have not been made our own by adoption, we are to examine, and so far vary from them as they may appear contrary to reason or unadapted to our local circumstances, the policy of our law, or simplicity of our practice'. ${ }^{23}$ As one of Reeve's students put it in the notebook he copied, '[t]he com'[mon] law of Eng. [land] [h] as been accepted so far as it has been considered as applicable to the local circumstances of [this] country; but where it has been considered as inapplicable it has been rejected' ${ }^{24}$ Here then was the opportunity to depart from English common law and English statutory law should there be the desire to do so.

The Connecticut legislature did not speak clearly when it turned its mind to the issue of whether or not married women would be allowed to make wills. When the state revised its laws in 1784, including its statute on testamentary capacity, it added the phrase 'and all others legally incapable' to the list of those who could not make a will. ${ }^{25} \mathrm{Had}$ the English statute made it notorious that married women were to be included among those 'others' who were rendered legally incapable? Or was it an exclusion that the legislature needed to make explicit? Deviation suggested meaningfulness, Reeve

\footnotetext{
${ }^{19}$ See A Fernandez, 'Tapping Reeve, Nathan Dane, and James Kent: Three Fading Federalists on Marital Unity' (Draft in-Progress).

${ }^{20}$ Reeve, Preface to Baron and Femme.

${ }^{21}$ See C Collier, 'Tapping Reeve, the Connecticut Common Law, and America's First Law School' (2006) 1 Connecticut Supreme Court History 13, 19.

${ }^{22}$ See EG Brown, British Statutes in American Law, 1776-1836 (Ann Arbor, MI, University of Michigan Press, 1964) 59, n 27. Reeve studied with Root in Hartford from 1770-72, served with him on several political committees, and succeeded to his seat on the Superior Court when Root was appointed Chief Justice in 1798; See CC Goetsch, 'The Litchfield Law School: A Modern View' (unpublished American Society for Legal History paper, 1979) (copies available at the Litchfield Historical Society \& Yale Law School Library) 10-11. The creation of 'Connecticut common law' would require reports of Connecticut cases and the cases for an American common law would have to come from somewhere. Root published a collection of Connecticut cases, Reports of Cases Adjudged in the Superior Court and Supreme Court of Errors, from July A.D. 1789 to June A.D. 1793, 2 vols (Hartford, CT, Hudson \& Goodwin, 1798-1802). He identified one of his motivations as providing an independent nation with its own judicial proceedings. See WW Horton, 'Day, Root and Kirby' (1996) 70 Connecticut Bar Journal 407, 413. Litchfield-based Ephraim Kirby produced the first set of print-published American reports in 1789. E Kirby, Reports of Cases Adjudged in the Superior Court of the State of Connecticut, from the year 1785, to May 1788 (Litchfield, CT, Collier \& Adam, 1789).

${ }^{23}$ See Z Swift, A System of the Laws of the State of Connecticut in Six Books, vol 1 (Windham, CT, Printed by John Byrne, 1795-96) 144 (relying on Wilford v Grant).

${ }^{24}$ Notebook of Seth Staples, vol 1 (1798) (Yale Law School Library) 10.

${ }^{25}$ See Reeve, Baron and Femme 156.
} 
argued, given that the statute was 'in many of its expressions ... a literal copy' of the English one. ${ }^{26}$ Here was a question at least.

The Connecticut Superior Court held in 1786 that the will a married woman made disposing of her own lands was void. ${ }^{27}$ This case, Adams $v$ Kellogg, was over-ruled by the Supreme Court of Errors, the state's highest court. Zephaniah Swift wrote in 1795-96, 'the law is now settled, that a married woman may make a devise of her own lands, even to her husband' ${ }^{28}$ Blackstone had written that a married woman could not will lands to her husband as she is 'at the time of making it [the will] she is supposed to be under his coercion' ${ }^{29}$ The worry was the usual one that a wife would be pressured by her husband to will her lands to him. Under English law, when a married woman died, her husband was granted 'curtesy' in her lands, a kind of life estate, but only if there were children of the marriage. The husband was never given the fee simple, which stayed with the wife's family. Reeve argued that a husband's curtesy should not depend on the birth of a child despite the rationale for the rule, which was to provide support for children of the marriage. ${ }^{30}$ Indeed, Reeve's advocacy for extended rights of curtesy and a married woman's power to make a will, even to her husband, raises the question of whether his was more a case of 'husband's rights' than 'women's rights', particularly for husbands like him from a modest background who married into families of power and wealth like his first wife, Sally Edwards Burr, whose family would have worried about a husband like him.

Zephaniah Swift was another important Connecticut jurist in this period. He too ran a law school but in the northeast part of the state (Litchfield was in the northwest). Swift wrote a number of important legal works, including A System of the Laws on the State of Connecticut in 1795-96 (a twovolume set of commentaries on Connecticut law) and a two-volume Digest of the Laws of the State of Connecticut in 1822-23. He is sometimes called 'the first American treatise writer' on the basis of this first book despite its Justinian-inspired persons-things-actions structure that made it more like Blackstone's Commentaries than a treatise on a discrete and specialised topic. ${ }^{31}$ Swift was a Democrat where Reeve was a Federalist. From 1801 to 1815, he and Reeve sat together on the Supreme Court of Connecticut (where both were eligible to sit on the once-a-year session of the Supreme Court of Errors). Not surprisingly, given their rival schools and political backgrounds that were almost literally at war with one another in Connecticut at this time, their views on the bench were 'often divergent' ${ }^{32}$ Swift was much more positivistic in his approach to the law than Reeve was. ${ }^{33}$ Swift wrote 'a commentator on the laws must take the laws as he finds them'. ${ }^{34}$ As Morton Horwitz put it, Swift "came as close as any jurist of the age to maintaining that law is what the courts say it is'. ${ }^{35}$ On the topic of married women, Swift was also much more conservative. He opposed separate estates on the grounds that husband and wife could not make a contract with one another and he and Reeve battled over this. ${ }^{36}$ Swift accepted Blackstone's maxim that the husband and wife were one person in law. Indeed, his version of the statement replaced Blackstone's emphasis on coverture with an emphasis on 'one will', which was, he wrote, 'placed in the husband' ${ }^{37}$ How then could a married woman make a

${ }^{26}$ Ibid 155.

${ }^{27}$ Adams v Kellogg (1796) 1 Kirby 195 (Ct. Sup. Ct.).

${ }^{28}$ Swift, System, vol 1, 325.

${ }^{29}$ Blackstone, Commentaries, vol 1, 432.

${ }^{30}$ See Reeve, Baron and Femme 30. Swift criticized the 'born alive' rule, which irrationally excluded children born by caesarean section and included those born who then died. Swift thought that the rule should either be that children were irrelevant (as Reeve desired), or that there should be a simple requirement of children who survive the wife and require support. See Swift, System, vol 1, 253.

${ }^{31}$ AWB Simpson, 'The Rise and Fall of the Legal Treatise: Legal Principles and the Forms of Legal Literature' (1981) 48 University of Chicago Law Review 632, 669. See also J Cohen, 'Swift, Zephaniah' in AWB Simpson (ed), Biographical Dictionary of the Common Law (London, Butterworths, 1984) 499 ('Swift's most important achievements ... were as one of the earliest American treatise writers').

${ }^{32}$ Horton, 'Day, Root and Kirby' (n 22) 418.

${ }^{33}$ See M Grossberg, Governing the Hearth: Law and Family in Nineteenth-Century America (Chapel Hill, NC, University of North Carolina Press, 1985) 22 (describing Reeve's approach as 'political' and 'reformist').

${ }^{34}$ Swift, System, vol 1, 292.

${ }^{35}$ MJ Horwitz, The Transformation of American Law, 1780-1860 (Cambridge, MA, Harvard University Press, 1977) 25. Thanks to Roman Hoyos for pointing me to Horwitz on Swift.

${ }^{36}$ The battle resulted in a compromise. Reeve was forced to concede that husbands and wives could not make contracts with each other and women could not have separate estates for their sole separate use and management. However, a married woman could have a separate estate if there was a trustee. See Nichols v Palmer (1811) 5 Day 47 (Ct. Sup. Ct. Errors).

${ }^{37}$ Swift, System, vol 1, 194 (also quoted at the outset of this paper). 
document purporting to be a reflection of her own will, no longer having one and residing in her husband? Although he must have disagreed with the result in the case, Swift dutifully recorded in his first work, A System of the Laws, what Adams v Kellogg said the law was — he might not like it but a married woman could make a will of her lands in Connecticut.

This issue, however, did not go away. Reeve and Swift would have found themselves on opposite sides of it as judges in the Supreme Court of Errors in 1805. In this case, Fitch v Brainerd, the court reversed itself, declaring that Adams $v$ Kellogg 'was not law' after all. ${ }^{38}$ After reviewing the relevant statutory and common law history, the court found that there was no established practice in Connecticut of allowing married women to devise. 'For near a century, femes-covert had no estate to devise. The custom for them to devise, if such it may be called, is very recent, as well as very limited - confined, so far as is known, to a few instances, and within the last twenty years' ${ }^{39}$ There is no indication in the report who wrote the decision, but it became known in Connecticut legal circles as the case in which Zephaniah Swift reconsidered how radical the departure from English law should be. ${ }^{40}$ Swift's first book, his System of the Laws, often argued from principle that the law should be this or that way. His second book in the 1820s is much less likely to start talking about how the law should be. It is a digest and in it he is obviously primarily concerned with gathering together what the state has now said the law is. ${ }^{41}$ However, in Fitch $v$ Brainerd, Swift could do as a judge (in concert with others) what he did not feel he could do as a legal writer even in 1795-96, namely, reverse a case he thought was bad law. Unlike Reeve, he did not think he could ignore it and say the law was the opposite of what a case from the state's highest court said it was.

Reeve, on the other hand, takes a completely different attitude. His two chapters on the willing issue in Baron and Femme do not refer to either Adams $v$ Kellogg or Fitch v Brainerd. He wrote that he would approach the issue 'independent of any authorities; as if it were a question wholly novel, respecting which there had been no adjudications, and was now to be decided upon principle. In such case, unshackled with precedents, nothing can govern us, in deciding the question, but what is reasonable and right' ${ }^{42} \mathrm{He}$ did not say there were no authorities. He said he would treat the question 'as if' there were none. ${ }^{43}$ We know that Reeve promulgated this 'as if' approach almost 15 years before he was over-ruled in Fitch $v$ Brainerd and he might have been doing it for even longer, strongly suggesting that he did not ignore Connecticut case law simply because it was unfavourable to him. Indeed, the earliest available version of these lectures on a married woman's right to make a will were given in 1791, at a time when he could have relied on Adams $v$ Kellogg to support him and did not. ${ }^{44}$ Authorities for or against were not determinative. '[I]f the authorities teach a different doctrine ... nothing more can be inferred from this, than that the law, in this instance, is unreasonable'. While admittedly, '[n]o maxim is of more utility to the community than stare decisis', Reeve wrote, 'we can never fail to decide on that side which is reasonable and right'. ${ }^{45}$ A de novo treatment, with complete disregard of the cases in the jurisdiction, was a perfectly legitimate way to arrive at a statement of what the law was.

Reeve's reasoning is a remarkable statement of pure principle given the absence of any connection to precedent. The spirit that motivated it seems very similar to the Supreme Court of Errors' blanket pronouncement that Adams $v$ Kellogg was no longer (and maybe never was) law. However, a court of law is authorised to issue such statements, make law or over-rule if necessary its previous decisions. In the hierarchy of formal sources of law, a treatise cannot do this, no matter how authoritative its author is. It can recommend that the law be changed (because it is bad, unreasonable, immoral, inefficient, ugly or for any other reason); but a common law treatise ignoring case law and setting out what the law is in opposition to what case law in the jurisdiction says stands in serious danger of simply being characterised as a bad treatise. So, for instance, in 1804, in a case called Dibble v

\footnotetext{
${ }^{38}$ Fitch v Brainerd (1805) 2 Day 163 (Ct. Sup. Ct. Errors) 194.

${ }^{39}$ Ibid.

${ }^{40}$ SE Baldwin, 'Zephaniah Swift' in W Draper Lewis (ed) Great American Lawyers, vol 2 (Philadelphia, PA, John C Winston, 1907) 101-44 117-18.

${ }^{41}$ Z Swift, A Digest of the Laws of the State of Connecticut 2 vols (New Haven, CT, S. Converse, 1822-23).

${ }^{42}$ Reeve, Baron and Femme 137.

${ }^{43}$ Ibid.

${ }_{45}^{44}$ Notebook of Eliphalet Dyer, vol 2 (1791) 74, Connecticut Historical Society.

45 Reeve, Baron and Femme 137.
} 
Hutton, the Supreme Court of Errors adopted the Coke/Blackstone version of the one-person-in-law maxim in no uncertain terms: 'By the common law, the husband and wife are considered as one person in law, the existence of the wife being merged in that of the husband, or suspended during the coverture ${ }^{46}$ How could Reeve continue to write what he did in Baron and Femme about this issue in the face of such a ruling? This was not just 'law-making by treatise' but over-ruling by treatise. ${ }^{47}$

Some contemporaries did see Reeve's treatise as a bad treatise. One former student, Edward Deering Mansfield, who moved to Ohio, 'the new Connecticut', and wrote his own (extremely conservative) book on married women's property rights, said that 'the lawyers admired [Reeve's treatise on Domestic Relations], but said [it] was not law, on account, I believe, of its leaning too much to women's rights'. ${ }^{48}$ In making this statement, Deering seems to have been politely saying that this is what he thought. I am sure Swift would also have viewed the book that way, both for its disregard for the positive law in Connecticut and for being too progressive on women's issues.

\section{Why Did Reeve Argue as he Did?}

Reeve's promotion of women's rights was almost certainly related to his religion. Reeve was an ardent Congregationalist, the traditional dominant sect of Calvinist Protestantism in New England, and he was very active in a movement known as the 'Second Great Awakening' in Connecticut, a long revival that took place in New England in the 1790s. Women had special roles to play in this kind of evangelical movement. They constituted the greatest number of converts during revivals, and they figured prominently in the organisational efforts of reform organisations, including anti-slavery and temperance groups. Indeed, the era has been called 'an age of female societies' given the importance of women in raising money and organising various charitable and other kinds of institutionally-organised activities. ${ }^{49}$ Women moved outside the domestic sphere in order to participate in these activities, raising their prominence and importance in areas that men like Reeve cared about and were impressed by the ability to make achievements in.

High numbers of female participants in religious activity in this period have led some scholars to speak about the 'feminization of Protestantism' ${ }^{50}$ Doctrines like infant damnation - something that caused particular distress to mothers who lost children before they could be baptised - came up for reconsideration. ${ }^{51}$ Fear of death in childbirth and fear of losing young children helps explain why women turned in such high numbers to religion and voluntary associations like prayer groups. ${ }^{52}$ Participating in religiously organised activities outside the home gave women an opportunity to express their 'moral, intellectual, and physical powers in other ways'. ${ }^{3}$ Piety (and particularly Calvinist self-examination) 'allowed women a sort of holy selfishness, or self-absorption ... requir[ing] attention to one's own thoughts, actions, and prospects'. ${ }^{54}$

Reeve's first wife, Sally, was actually the grand-daughter of the architect of the 'First Great Awakening', Jonathan Edwards, the religious movement in the 1740s that originally split revivalists

${ }^{46}$ Dibble v Hutton (1804) 1 Day 221 (Ct. Sup. Ct. Errors) 235.

${ }^{47}$ M Moers Wenig, 'The Marital Property Law of Connecticut: Past, Present and Future' (1990) Wisconsin Law Review 807, 844.

${ }^{48}$ See E Deering Mansfield, Personal Memoirs: Social, Political, and Literary, with Sketches of Many Noted People, 1803 1843 (Cincinnati, OH, Robert Clarke, 1879) 127. Deering supported allowing married women to make wills but in his book, written for women, encouraging them to celebrate the loss of personal independence upon marriage, he provided the one-person-in-law maxim with biblical support and reversed everything Reeve taught him about the powers and independence of married women. See E Deering Mansfield, Legal Rights, Liabilities, and Duties of Women (Salem, MA, John P Jewett, 1845) 211, 262-63, 273.

${ }^{49}$ See CR Keller, The Second Great Awakening in Connecticut (New Haven, CT, Yale University Press, 1942) 233.

${ }^{50}$ See NF Cott, The Bonds of Womanhood: 'Woman's Sphere' in New England, 1780-1835 (New Haven, CT, Yale University Press, 1977) 132. See also B Welter, 'The Feminization of American Religion: 1800-1860' in MS Hartman and LW Banner (eds), Clio's Consciousness Raised: New Perspectives on the History of Women (New York, NY, Harper \& Row, 1974) 137-57; RD Shiels, 'The Feminization of American Congregationalism, 1730-1835' (1981) 33 American Quarterly 46.

${ }^{51}$ See Welter, 'The Feminization of American Religion', ibid 139.

${ }^{52}$ See Cott, The Bonds of Womanhood (n 50) 144.

${ }_{53}^{53}$ Ibid 138 .

${ }^{54}$ Ibid 140. 
and non-revivalists in both Congregational and Presbyterian communities in New England; 'New Lights' accused 'Old Lights' of being asleep in a dead religion. ${ }^{55}$ Individuals like Timothy Dwight, Joseph Bellamy and Lyman Beecher created a school in the 'Second Great Awakening' known as 'New Divinity'. These were the descendants of Edwards who, rather than revolting against strict Calvinist doctrines relating to issues like pre-destination as Unitarians did, 'fought for orthodoxy within the church through revivals, modifying it, liberalizing it, rendering it more acceptable by making it more reasonable'. ${ }^{56}$ Dwight was related to Reeve by marriage - his mother was another of Jonathan Edwards' daughters. ${ }^{57}$ Reeve's brother-in-law, Sally's brother, none other than Aaron Burr, studied theology with Bellamy prior to coming to Litchfield to study law with Reeve. ${ }^{58}$ Burr was alone among the founding fathers for holding anything remotely like feminist views, which it is a mistake to try to understand without a sense of his neo-Edwardsean background. ${ }^{59}$ Sally and Aaron Burr's father, Aaron Burr Senior, was the first president of the College in New Jersey that would become Princeton, originally organised as a 'New Light' institution. Their mother, Esther Edwards Burr, was an intellectual woman deeply steeped in the traditions of pious self-examination. ${ }^{60}$ Beecher was a close associate of Reeve's when Beecher was in Litchfield. ${ }^{61}$ Beecher gave a special sermon for Reeve when he died. ${ }^{62}$ In it, Beecher claimed Reeve for New Divinity. ${ }^{63}$ He also noted that Reeve visited many individuals engaged in the conversion process, saying that no one viewed more people or was more familiar with their conversion experiences. ${ }^{64}$ This brought Reeve into exchanges with women in his community who were also active in the movement. ${ }^{65}$ He supported a school for girls that some have said offered more than training in the elegant accomplishments. ${ }^{66}$

Revivalist Congregationalism actually contained the seeds of an equality-oriented understanding of women and the husband-wife relation. The idea of marriage as friendship had antecedents in the religious philosophy of New Light Divine, John Witherspoon. ${ }^{67}$ One of Reeve's students who sat with him for a time as a judge and would go on to become governor of Connecticut, John Cotton Smith, noted that Reeve allowed Sally to remain in control of the fortune she inherited from her family. Smith remembered that, like his own father, who allowed his mother to retain control of her own property, the two men rejected 'that portion of the old English Common Law which takes away all property rights from married women. Both of them had shown their faith by their works' ${ }^{68}$ The religious formulation is no mere adornment. New Divinity deeply informed where these people were coming from. There is probably a connection between it and the rough equality of the sexes that Cornelia Hughes Dayton has found in older Puritan culture. ${ }^{69}$ Reeve and Smith were both involved in

\footnotetext{
${ }^{55}$ See generally WG McLoughlin' in Revivals, Awakenings, and Reform: an Essay on Religion and Social Change in America, 1607-1977 (Chicago, IL, University of Chicago Press, 1978).

${ }^{56}$ Keller, The Second Great Awakening (n 49) 229.

${ }^{57}$ See DH Fischer, 'Dwight, Timothy' in The Revolution of American Conservatism: the Federalist Party in the Era of Jeffersonian Democracy (New York, NY, Harper \& Row, 1965) Appendix II 286-88.

${ }^{58}$ N Isenberg, Fallen Founder: The Life of Aaron Burr (New York, NY, Penguin, 2007) 16.

${ }^{59}$ Ibid 413 (calling Burr 'the only founder to embrace feminism'). Isenberg points out that Burr was a great admirer of Mary Wollstonecraft's Vindication of the Rights of Woman and thought there should be an American version. She thinks he thought he was the one to write it. See ibid 240.

${ }^{60}$ See CF Karlsen and L Crumpacker (eds), The Journal of Esther Edwards Burr, 1754-1757 (New Haven, CT, Yale University Press, 1984).

${ }^{61}$ See B Cross (ed), Autobiography of Lyman Beecher, vol 1 (Cambridge, MA, Harvard University Press, 1961) 156, 17072.

${ }^{62}$ L Beecher, 'Memoir of the Honourable Tapping Reeve' (Feb, 1827) Christian Spectator 62.

${ }^{63}$ Beecher described Reeve's views as those 'explained and vindicated ... by Edwards, and Bellamy, and West, and Hopkins, and Dwight'. Ibid 67. Reeve's list of books included titles like 'Edwards's works', 'Bellamy's Discourses' and 'Dwight's Theology'. See 'Copy of Tapping Reeve's Inventory. Re[ceived] \& accepted Feb[ruar]y 14th AD. 1824. F Wolcott, Judge', Litchfield Historical Society.

${ }^{64}$ Beecher, 'Memoir' 66-67. See also Autobiography of Lyman Beecher, vol 1, 272-77.

${ }^{65}$ See, eg Tapping Reeve to Maria Cushman, [?27?] November 1814, Litchfield Historical Society.

${ }^{66}$ See AM Siegel, “To Learn and Make Respectable Hereafter': The Litchfield Law School in Cultural Context' (1998) 73 New York University Law Review 1978.

${ }^{67}$ Isenberg, Fallen Founder (n 58) 72.

${ }^{68}$ H Evertson Smith, Colonial Ways and Days (New York, NY, Century, 1900) 304-5 (emphasis added).

${ }^{69}$ See C Hughes Dayton, Women Before the Bar: Gender, Law and Society in Connecticut, 1639-1789 (Chapel Hill, NC, University of North Carolina Press, 1995); C Hughes Dayton, 'Was There a Calvinist Type of Patriarchy?' in CL Tomlins and BH Mann (eds), The Many Legalities of Early America (Chapel Hill, NC, University of North Carolina
} 
the Connecticut Bible Society. John Cotton Smith was its first president and Reeve was a local agent. ${ }^{70}$ Smith was known as the last Puritan governor, as he was the last Federalist Governor in Connecticut prior to religious disestablishment in the state. ${ }^{71}$ The surprisingly progressive views about married women's property rights we find in Reeve's lectures and writing must be understood against this religious background. And his insistence on pure principle is probably motivated in part by how desperate the larger war had become by the time he published the book in 1816.

Federalists lost control of the state in 1817 when the 'Stelligeri' or Democrats challenged the Federalist 'Standing Order' and won. Swift, a Deist, was an early member of this group. ${ }^{72}$ Connecticut's first constitution was enacted shortly thereafter, in 1818, and it brought in disestablishment of the Congregationalist religion. ${ }^{73}$ It also adopted the Federal Constitution's separation of powers between the legislative, executive and judicial branches of government. This is something Swift had long advocated and it is indeed one of the things he is chiefly remembered for. ${ }^{74}$ So, prior to this change, the Supreme Court of Errors was a court that mixed legislative and judicial functions, like the 'General Court' of the colonial period in Massachusetts. ${ }^{75}$ To modern eyes, this might explain why Reeve did not show a lot of respect for the cases produced by the Supreme Court of Errors. ${ }^{76}$ However, I think that this would not have been grounds for disrespect to Reeve, as he was a staunch proponent of that pre-1818 'mixed' tradition. Indeed, I think, just the opposite, he would have seen himself - literally, in his physical person - as if he were a source of law, whether he was standing lecturing in front of his students, sitting in the state courts or writing his book.

So, for instance, when discussing in Baron and Femme the question of seisin and whether 'seisinin-fact' was required in order for a husband to take curtesy in his deceased wife's land as in England, or whether 'seisin-in-law' would be sufficient, Reeve quoted from the following 1810 case, Bradley $v$ Bush: 'our system of law respecting real property, is, in many instances, very different from the English system ... if we reject our own [rule], and adopt theirs, we shall mar the symmetry of our law'. ${ }^{77}$ This is a great example of a classical Connecticut rejection of English common law, consistent with the training and orientation Reeve would have received from Jesse Root. The court held here that actual seisin of a wife's lands was not required for a husband's curtesy. What Reeve does not point out in his discussion of this in the book is that this was in fact one of his own decisions. The words quoted from are actually his own. ${ }^{78}$ Here is Reeve blurring the boundaries of his different roles, judge and treatise-writer, so as to achieve persuasive effect in his teaching book. Calling Bush v Bradley a case where 'seven of the judges concurred', with not a whisper of his own involvement as he did, sounds a lot more detached, objective and ultimately more convincing than saying, 'as I said in Bush v Bradley, this is an important principle, and I got the others to agree'. Like the mixed and blurry legal, political and religious order he was struggling to maintain, Reeve was not going to think too much about a separation of identities or distinguishing between the different capacities in which he was operating. Publication of the book in 1816 of what he had been teaching all those years certainly must be understood as a last hurrah for the world-view that he embodied. It was one due to be replaced by Swift's, who did actually replace him as Chief Justice in $1815 .^{79}$

Press, 2001). See more generally, RJ Ross, 'The Career of Puritan Jurisprudence' (2008) 113 Law and History Review 975.

${ }^{70}$ See Keller, The Second Great Awakening (n 49) 110-11.

${ }^{71}$ Ibid 58.

72 See DF Gerardi, 'Zephaniah Swift and Connecticut's Standing Order: Skepticism, Conservatism, and Religious Liberty in the Early Republic' (1994) 67 The New England Quarterly 234, 239.

${ }^{73}$ See ML Greene, The Development of Religious Liberty in Connecticut (New York, NY, Houghton, Mifflin, 1905).

${ }^{74}$ See Swift, System, vol 1, 28. See, eg EC Goodwin, The Magistracy Rediscovered: Connecticut, 1636-1818 (Ann Arbor, MI, UMI Research Press, 1981) 1, 95-115.

${ }^{75}$ See CA Desan, 'Remaking Constitutional Tradition at the Margin of the Empire: The Creation of Legislative Adjudication in Colonial New York' (1998) 16 Law and History Review 258; 'The Constitutional Commitment to Legislative Adjudication in the Early American Tradition' (1998) 111 Harvard Law Review 1381.

${ }^{76}$ See, eg SE Baldwin, 'Historical Sketch of the Supreme Court of Errors of Connecticut' in B Clark (ed), The Supreme Court of the States and Provinces of North America, vol 1 (New York, NY, Medico-Legal Journal, 1895) 384 (where Baldwin suggests that this body does not become a real court until 1808).

${ }^{77}$ Reeve, Baron and Femme 33.

${ }^{78}$ See Bush v Bradley (1810) 4 Day 298 (Ct. Sup. Ct. Errors) 305.

${ }^{79}$ Horton, 'Day, Root and Kirby' (n 22) 418. 
Reeve fought hard against the transfer of ruling power away from the Federalists on a national level. He wrote in one of Litchfield's newspapers against Thomas Jefferson with a vehemence that landed him in a seditious libel prosecution under the Alien and Sedition Act. ${ }^{80}$ Swift embodied much of the new order - a positivist orientation in law book writing (cases and statutes matter, they cannot simply be ignored); more clearly delineated roles for judges and law teachers writing treatises (you can over-rule a case as a judge but not as a treatise writer); conservatism on married women's property rights; a separation of church and state; and a separation of powers. Swift would win the war and not just in Connecticut. However, there was one battle Reeve won. He got his students to do what Fitch v Brainerd said would have to be done in order to allow married women to make wills, namely, pass a statute empowering them to do so. ${ }^{81}$

This remarkable and extremely short statute in 1809 set out simply that 'married women shall have the power of disposing of their estates by last will and testament'. ${ }^{82}$ There were at least 15 of Reeve's former students in the House of Representatives when it was passed. ${ }^{83}$ Among these was the Speaker of the House, Lyman Law. Law attended the school the same year as another student, Eliphalet Dyer, and Dyer's notebooks show that the students that year were treated to an essay by Reeve entitled 'Can a feme covert by the laws of Connecticut devise her real Estate?' This essay substantially reproduces what was later included in the two chapters of Baron and Femme. ${ }^{84}$ John Cotton Smith was also a member of the May 1809 legislative session that passed this statute, as were several classmates from his year. We know Smith was ideologically on board, given the comments he made about his own mother and Sally Reeve noted above. He was also a general proponent of Reeve's views, helping in the publication of Reeve's second book after Reeve's death. ${ }^{85}$ Referring to Reeve's 'celebrated pamphlet on "The Domestic Relations"', Smith noted that Reeve's was 'the first voice ever publically raised in our country ... in [sic] behalf of the property rights of married women' ${ }^{86}$ While he may have 'stood almost alone among the lawyers of his day', Smith recalled, 'in his school he made many disciples' ${ }^{87}$ Another former student wrote that Reeve's treatment of 'the axiom that "a married woman has no will of her own"" caused his students to leave the lecture room 'the very knight errants of the law burning to be the defenders of the right and avengers of the wrong; and he is no true son of the Litchfield school who has ever forgot that lesson' ${ }^{88}$ It stands to reason that these Litchfield sons, disciples, knight errants, changed the law when they had the opportunity to do so.

Swift was forced to write in his Digest of the Laws, '[w]hether a married woman can devise her lands is a question that has been much agitated, but the legislature have put it to rest, by giving her that power'. ${ }^{89}$ Why would Reeve have failed to take note of this in his own book?

\footnotetext{
${ }^{80}$ See RG Wetmore, 'Seditious Libel Prosecutions in 1806 in the Federal Court in Connecticut: United States v. Tapping Reeve, and Companion Cases' (1983) 57 Connecticut Bar Journal 196. One study concluded that the prosecution was dropped because Reeve was 'a nationally revered figure'. See CA Heckman, 'A Jeffersonian Lawyer and Judge in Federalist Connecticut: The Career of Pierpont Edwards' (1996) 28 Connecticut Law Review 669, 701.

${ }^{81}$ Fitch v Brainerd (n 38) 194.

82 'An Act in Addition to 'An Act relating to the age, ability and capacity of Persons", ch VII, 1809 Connecticut Public Acts 15 (May Sess. 1809).

${ }^{83}$ Shubael Griswold (1809); Roger Whittlesey (1788); Ezekiel P Belden (1797); Joseph Bulkley (1810); Nathan Smith (1790); Augustus Collins (1804); John Kingsbury (1788); Lyman Law (1791); Samuel Blackman (1796); James Stevens (1796); Aaron Smith (1791); John C Smith (1788); Daniel Brindsmyaide (1803); Phineas Miner (1796); and Noah B Benedict (1789). This list was generated by cross-referencing the names and years of attendance from Samuel $\mathrm{H}$ Fisher, Litchfield Law School, 1774-1833. Biographical Catalogue of Students (New Haven, CT, Yale University Press, 1946) with the 109-person list of the members of the House of Representatives, May Session, 1809 in Roll of State Officers and Members of General Assembly of Connecticut 1776 to 1881 (Hartford, CT, Case, Lockwood \& Brainard, 1881) 173175.

${ }^{84}$ Notebook of Eliphalet Dyer, vol 2, 74. Comparative analysis on file with the author.

${ }^{85}$ T Reeve, A Treatise on the Law of Descents in the Several States of America (New York, NY, Collins \& Hannay, 1825); See J Calder, Life and Times of Tapping Reeve and his Law School (Paper prepared pursuant to a Master's Degree, University of Vermont \& Litchfield Historical Society Internship, 1978) (copies available at the Litchfield Historical Society \& Yale Law School) 28.

${ }^{86}$ Smith, Colonial Ways and Days (n 68) 304.

${ }^{87}$ Ibid.

${ }^{88}$ DC Kilbourn, The Bench and Bar of Litchfield County, Connecticut, 1709-1909: Biographical Sketches of Members, History and Catalogue of the Litchfield Law School, Historical Notes (Litchfield, CT, 1909) 187. This former student was Charles Loring. He attended in 1813.

${ }^{89}$ Swift, Digest, vol 2, 39.
} 
The substantial similarity between Dyer's essay and what ultimately appeared in Baron and Femme makes one wonder whether Reeve simply failed to update his lectures before publishing the book. We know he was keen to receive the proceeds from book sales after he was forced to retire from the bench in 1815 and lost that portion of his income. ${ }^{90} \mathrm{He}$ wrote to one student, 'I have arrived at that time in my life that I can no longer hold a seat on the Bench so that I have to depend on my school and the books I publish for a livelihood'. ${ }^{91}$ Perhaps he was in too much of a rush to publish to update. However, he did make one change in the text in response to Fitch $v$ Brainerd. ${ }^{92}$ This shows that Reeve was not simply dropping the lectures into his text holus-bolus with no thought about what had happened to the topic over the 25 years he had been teaching it.

It is possible that Reeve saw legislation as too vulnerable to change to be part of the law Baron and Femme described. His students banded together and passed the law; but it could be undone by a future similar campaign in the legislature. I do not think that his failure to discuss the statute, which he must surely have known about given the size of the legal community, his place in it, and his great interest in this subject, was due to a general contempt for statutory law. He discussed English statutes at length but not this local statute. He also included English cases but not local ones. Unlike Swift, who deliberately put Connecticut in the title of his works and showed no hesitancy about describing the law in the state, Reeve set out in Baron and Femme to describe the English common law in such a way as 'to render the book, if of any value, equally valuable to all parts of our country'. ${ }^{93}$

Swift's more local focus explains why his work is not more well-known and why it was not included in Pound's speeches on the textbook teaching tradition. Yes, Swift was producing textbooks. Yes, he was even a teacher as well as a judge. However, Swift would not have been thought to have a sufficiently national perspective, a key component of the full-time Harvard Law School model Pound promoted. Reeve, on the other hand, took himself to be describing English common law that could form the basis of an American common law. Here was the orientation fellow-Federalists like Kent (in New York) and Dane (in Massachusetts) would have found appealing, the same one that would have contributed to Pound's choice to place Reeve at the beginning of the 'tough-law' textbook tradition. If it was somehow 'soft' to try to describe local state rules as they were embodied in cases and statutes from a particular jurisdiction that practitioners from that jurisdiction cared most about, this inverted the usual dichotomy between the tough/hard/masculine world of practice and the weak/soft/effeminate academic world. The fact that we know about Reeve but not about Swift is connected to a larger struggle over the professionalisation of law teaching and the triumph of the full-time Harvard model over part-time practitioners and judges in the twentieth century's conception of the best kind of academic legal education. However, this is too large a story to recount here. ${ }^{94}$

It is tempting then to excuse Reeve's failure to discuss the Connecticut cases and statute on the willing issue on the grounds that this was, unlike Swift, simply not his project. Reeve wrote that the 'object' of the work was 'to exhibit the Common Law of England and such of their Statutes as we have adopted in words or principle'.$^{95}$ Baron and Femme was intended to be a description of English law. However, at the same time, Reeve gave himself the option of referring to Connecticut when it

\footnotetext{
${ }^{90}$ A state statute in 1811 brought in mandatory retirement at age 70, which Reeve reached in 1815 . See Baldwin, 'Historical Sketch of the Supreme Court of Errors' (n 76) 387.

${ }^{91}$ Tapping Reeve to Samuel Law, 4 March 1817, Litchfield Historical Society, Litchfield, Connecticut. Once he was forced to retire from the school, Reeve's financial situation worsened. See Calder, The Life and Times of Tapping Reeve (n 85) 27-28. A letter sent to students to raise money for him in 1822 is reproduced in MC McKenna, Tapping Reeve and the Litchfield Law School (Dobbs Ferry, NY, Oceana Publications, 1986) 199-200.

92 The essay in Dyer's notebook asked: 'Are the rights of an Heir of a feme more [?favoured?] than those of a Baron[']s?' Reeve left this rhetorical question out of Baron and Femme, since Fitch v Brainerd had made it clear that actually, yes, unless the legislature made it otherwise, the contingent rights of an heir were more favoured than those of a husband. Notebook of Eliphalet Dyer, vol 2, 75.

${ }^{93}$ Reeve, Preface to Baron and Femme.

${ }^{94}$ Part of it is that Harvard chose Litchfield as the place to trace its intellectual lineage and Simeon Eben Baldwin chose Swift for Yale. I describe this adoption of allegiances and its mapping onto the larger struggle for the professionalisation of legal education in A Fernandez, 'Spreading the Word: From the Litchfield Law School to the Harvard Case Method' (JSD Dissertation, Yale Law School, 2007).

${ }^{95}$ Reeve, Preface to Baron and Femme.
} 
was favourable to do so. ${ }^{96}$ This approach, a description of English law that could selectively refer to Connecticut but need not do so, is what allowed Reeve to ignore a case like Dibble v Hutton in which a Connecticut court actually said that the Coke/Blackstone maxim was a correct statement of the common law and continue to write as if this was undecided in Baron and Femme. He and Swift could fight it out over this in the Supreme Court of Errors and Reeve could lose; yet, this had no effect on how the common law could be formulated in the version of English law imagined and possibly followed by other states. We might think of this as a fictional or mystical notion of English law. It could not be actual English law if it was impossible to find a single English lawyer who would reject Coke and Blackstone on the point. This was a local battle in Connecticut, which Reeve lost. Yet all of this is invisible in the treatise, as was also the larger tectonic shifts of power and authority in the state. However, Reeve was using the book to continue the fight in the only way he could, writing for lawyers in other states, whom he hoped would find his version of the common law persuasive. This is typical of fading Federalist jurists like James Kent who used their law teaching and didactic writings to continue to exert influence that it becomes impossible for them to exert in the political world. As Daniel Hulsebosch has put it:

Federalists turned to the nonlegislative dimensions of law and legal training, the areas of legal culture that were beyond the reach of electoral politics ... [I]f they could not control decision making directly, they could try to control the raw material on which decisions were made: the reports, treatises, handbooks, and educational institutions that inculcated law's purpose ... [resulting in the] painstaking acculturation of lawyers and judges in a supposedly nonpartisan legal culture. $^{97}$

In is unsurprising that Reeve faced with the sea-changes he was tried to exert influence in this way with his book and among his students. Given the connections between Federalism and religion, at least in Connecticut, ${ }^{98}$ and Reeve's religion and his views on married women's rights, this is surely an example of a New England scholar using 'scholarly means to evangelical ends'. ${ }^{99}$ What we must notice, however, is how paradoxical it is for Reeve to have used English law in the way he did, to harness its authority while at the same time undermining it with a quintessentially Connecticut or Puritan-based jurisprudence that strongly rejected English law and a maxim as fundamental as oneperson-in-law.

\section{Conclusions}

Although Reeve called his book a description of English law, it was struggles in his own state and his involvement in them that made him passionate about married women's property rights and influenced the content of his 'teaching and preaching attitude'. ${ }^{100}$ His views were strongly rooted in New England and Connecticut culture and concerns, most notably the equality-oriented idea of marriage underlying his desire to reverse the one-person-in-law maxim. However, by calling his views English law and by leaving out of the book the twists and turns in his battles with Swift, Reeve studiously avoided any sense that his ideas and views were Connecticut-specific. Indeed, given the simple description of what was 'reasonable and right', it was difficult on the basis of Reeve's text to understand what was controversial about allowing married women to make wills or why married women would ever be described as of one will with their husbands. Unlike Swift, Reeve did not put

\footnotetext{
${ }^{96}$ The way Reeve put it was to say that he has 'seldom mentioned the law of the state in which he lives; unless that difference arises in causes equally operative in all parts of the Union where it differs from the Common Law; or where an explanation of it has, in his opinion, served the purpose of shedding light upon the Common Law'. Ibid.

${ }^{97}$ DJ Hulsebosch, Constituting Empire: New York and the Transformation of Constitutionalism in the Atlantic World, 1664 1830 (Chapel Hill, NC, University of North Carolina Press, 2005) 278-79.

${ }^{98}$ Keller, The Second Great Awakening (n 49) 56 ('Religion must be kept in mind when attempting to explain Federalism in Connecticut at any rate').

${ }^{99}$ L Stevenson, Scholarly Means to Evangelical Ends: The New Haven Scholars and the Transformation of Higher Learning in America, 1830-1890 (Baltimore, MD, Johns Hopkins University Press, 1986), referred to in SA Siegel, 'Joel Bishop's Orthodoxy' (1995) 13 Law and History Review 215, 252.

${ }^{100}$ C Grasso, A Speaking Aristocracy: Transforming Public Discourse in Eighteenth-Century Connecticut (Chapel Hill, NC, University of North Carolina Press, 1999) 264 (quoting Yale president Ezra Stiles).
} 
'Connecticut' in the title of the work. He wanted to provide an account that could be adopted in all states, even if it was informed by New England and Connecticut in its essential aspects. In other words, he was, like a good Federalist, teaching and providing didactic works that could be used to build a common national account, an American common law. This national dimension explains Pound's interest in Reeve and the placement of Baron and Femme at the beginning of a 'tough' 'taught law' tradition despite the fact that Reeve's operation was pre-professionalised and very different from the Harvard full-time teaching model Pound was promoting. ${ }^{101}$ Reeve was producing an account he was trying to export, in the physical bodies of his students and in their notebooks. In this way and through publication of the lectures in his book, Reeve might manage to 'Connecticutize the world'. ${ }^{102}$

Given the way that Blackstone made one-person-in-law part of the political and legal firmament of the nineteenth century, it is difficult to appreciate in retrospect that here was a moment in which things really could have been different. ${ }^{103}$ As Dirk Hartog has demonstrated in his work on the law of husband and wife, in actual fact, coverture was constantly being outweighed by other policies in the courtroom, which provided public recognition of the separate legal identities of wives. ${ }^{104}$ The legal fiction, in other words, was often rejected as the fiction it was. ${ }^{105}$ Laura Edwards points out that enthusiasm for Blackstone on one-person-in-law was by no means universal. ${ }^{106}$ 'Variant readings', of which Reeve was certainly one, "were very much in evidence in the late eighteenth and early nineteenth centuries'. ${ }^{107}$ What looks to us now like a very particular version of the local, Reeve's Connecticut, might well have come to be the generally and nationally shared view. So, for instance, relying on Baron and Femme, Nathan Dane wrote in his digest and abridgement of American law in 1823 that because married women can do many of the things that presuppose separate legal existence (eg being liable to punishment for crimes, being a guardian, giving a receipt), the one-person-in-law maxim was 'now almost done away [with]'. ${ }^{108}$ That is really quite a remarkable statement. Here was a moment in which what I have argued was Reeve's locally-inspired view powered the resistance of Blackstone at a national level. ${ }^{109}$ Yes, Reeve lost to Swift in Connecticut. However, there was still the chance that Reeve's Connecticut-informed view might actually become American common law. The fact that it did not heightens the need to understand how things might have been different, and how they were in fact different at different times and places, both on-the-ground and in-the-books.

${ }^{101}$ These lectures were given two years before the United States Supreme Court ruled that there was no federal common law that federal courts could use when hearing state claims under diversity jurisdiction. However, in 1936, Swift v Tyson, Joseph Story's creation of federal common law for the states was still controlling. See Erie Railroad Co v Tompkins, 304 US 64, (1938); Swift v Tyson, 41 US 1 (1842).

${ }^{102}$ Grasso, 'A Speaking Aristocracy' (n 100) 376 (quoting from a biography of Timothy Dwight by Kenneth Silverman).

${ }^{103}$ Unjustifiably, as scholars like Mary Beard have shown. Beard's argument was that Blackstone completely ignored equity when he stated that husband and wife were one-person-in-law. See M Beard, Women as Force in History: A Study in Traditions and Realities (New York, NY, Collier Books, 1962). See also Stretton (n 2) (tracing the older history of oneperson-in-law, showing that while it was present in legal writing before Blackstone, Blackstone gave it its most significant force and effect).

${ }^{104}$ See Hartog, Man and Wife in America (n 3$)$ 128-31.

${ }^{105}$ See ibid 107.

${ }^{106}$ LF Edwards, The People and Their Peace: Legal Culture and the Transformation of Inequality in the Post-Revolutionary South (Chapel Hill, NC, University of North Carolina Press, 2009) 104 ('[S]outherners in the late eighteenth and early nineteenth centuries were decidedly less enthusiastic about Blackstone's version of domestic authority than later generations - and later historians').

${ }^{107}$ Ibid 105.

${ }^{108}$ Dane (n 13), vol 1, 332.

${ }^{109}$ On the importance of the 'local', its connection to public conceptions of the peace, and its contra-distinction to formal sources of state law (cases, statutes, legal treatises), see Edwards, The People and Their Peace (n 106). Edwards takes Reeve's Baron and Femme to be a typical example of the latter category rather than the former, helping to create universal rules based in individual rights at the state level that excluded localised law. See 251-53. 